\title{
The Foam Concretes on the Activated Mixing Water
}

\author{
Nikolay Karpenko1, Vladimir Erofeev², Denis Emelyanov², Valery Fomichev³ ${ }^{3}$ Alexey Bulgakov4*, \\ Aleksandr Matvievskiy5, llia Tretiakov² \\ ${ }^{1}$ Laboratory of Strength and Quality Problems in Construction, Research Institute of Building Physics of the Russian Academy of \\ Architecture and Building Sciences, 127238 Moscow, 21 Locomotive travel, Russia \\ 2 Department of Building Materials and Technologies, Faculty of Architecture and Construction, National Research Mordovia \\ State University, 430005 Saransk, 68 Bolshevistskaya st., Russia \\ ${ }^{3}$ Department of General and Inorganic Chemistry, Institute of Architecture and Civil Engineering, Volgograd State Technical \\ University, 400005 Volgograd, 28 Lenin Avenue, Russia \\ ${ }^{4}$ Department of Mechatronics and Hydraulic Drive, Faculty of Mechanical Engineering, South-Russia State Polytechnic University, \\ 346428 Novocherkassk, 132 Prosveshchenia st., Russia \\ 5 'Maxmir' Open Joint-Stock Company, 121099 Moscow, 11 Novinsky Boulevard, Russia \\ * Corresponding author, e-mail: agi.bulgakov@mail.ru
}

Received: 12 October 2018, Accepted: 23 December 2018, Published online: 17 April 2020

\begin{abstract}
The paper presents the results of studies of the physical and mechanical properties of foam concrete on activated mixing water. Corrosion resistance of reinforcing steel in foam concrete with the use of activated water in the presence of mineral additives was studied. The use of activated with the electromagnetic field and electric current water of mixing enhances strength characteristics and reduce shrinkage deformation of composites. The increase of water resistance of foam concretes prepared on activated water of mixing compared with control compositions it was established. The comparative characteristic of foam concrete on the two types of foaming agent is given. The results of the anodic behavior of steel in activated water, characterizing the degree of aggressive influence on the steel depending on the activation mode and the chemical composition of mineral additives. This paper is a revised version of the paper (study) published earlier in the proceedings of the Creative Construction Conference 2018 (Karpenko et al., 2018).
\end{abstract}

\section{Keywords}

foam concrete, activation water of mixing, foam stability, foam multiplicity, durability, water resistance, shrinkage, corrosion resistance

\section{Introduction}

Among the large variety of modern building materials used in construction, significant amounts fall on foam and aerated concrete. These materials are widely used in the construction of buildings and structures, in heat-insulating products. In recent years, the production of foam concrete has outpaced the use of aerated concrete. Due to the toughening of the thermal engineering standards for heat-insulating materials, it is important to improve the physical, mechanical and operational properties of foam concrete.

Along with a large variety of materials and products of cellular structure of particular interest in the study is reinforced foam. Despite the fact that foam concrete has a number of positive qualities - tensile resistance is not one of them, which undoubtedly determines the use of reinforcement. Based on this, the study of the behavior of reinforcing steel, namely its corrosion resistance, in foam concrete is an urgent task.
Many authors have established that the quality management of concretes and other composite materials is possible with different impacts on both non-hardened and hard materials and on its components. At present, there is a wide range of technological methods that allow purposefully regulate the structure, and therefore the properties of cement stone, among which are the use of fillers of different nature and fractional composition, the activation of individual components and concrete mixtures themselves (Deuse et al., 2009; Emelyanov et al., 2014a; Emelyanov et al., 2014b; Fedosov et al., 2011; Fokin and Loshkanova, 2008; Kalashnikov, 2011; Kalashnikov et al., 2014; Karaseva, 2008; Ulazowski and Ananina, 1975; Povkh et al., 1971).

Water is a required component for cement composites and water determines their technological properties. In our previous studies, we investigated the effect of electrochemical and electromagnetic activation (using electric 
current and the electromagnetic field to get changes in the physical and chemical properties of water) and proved the improvement of the physical and mechanical properties of cement stone and heavy concrete due to the use of activated mixing water (Bazhenov et al., 2011; Erofeev et al., 2007; Erofeev et al., 2008; Erofeev et al., 2014). In this paper, we present studies of the production technology and physical and mechanical properties of foam concrete with the use of electrochemically and electromagnetically activated mixing water. From the results given below it follows that such mixing water activation in foam concrete gives an even greater effect. It is known that the formation of foam concrete with the optimal structure is possible under the condition of a combination of numerous physico-technical and physicochemical factors: the viability of the foam film, composition, density and other properties of the foam concrete.

The hydrodynamic effect is one of the factors determining the viability of the foam film. According to the theory of structural and mechanical stability of foams, the stability of adsorption layers is determined both by surface forces and by mechanical properties of foamed films (Kruglyakov and Exorova, 1990). If there is some way to improve these properties, it will increase the stability of foam. It is the provision of a structural-mechanical stability factor that can give the foam the greatest stability. Below we present studies of the effect of activated water, both on the foam properties and on the properties of foam concrete.

The ability of surfactants to form micelles to a significant extent depends on the length of hydrocarbon radical (Kruglyakov and Exorova, 1990). Their sizes depends on the concentration above which micelles form (the critical micellization concentration, CMC) (Portik, 2003). There are many methods for determining CMC. All of them are based on a sharp change in the physicochemical properties of surfactant solutions in the transition from a molecular solution to a micellar solution.

Thus, the creation of a foam and mixtures of foam concrete with stable structure possible with the use of activated water and aqueous solutions for mixing.

\section{Description of the conceptual design}

To study aqueous solutions of foaming agents, foam, cement stone and foam concrete, we used the following components: we took portland cement CEM I $42.5 \mathrm{~B}$ as a binder (GOST 31108-2016 (LLC Cemiskon, 2016)); as foaming agents: "Esapon 1850" - non-ionic surfactant, which is a saturated fatty alcohol with ethylene oxide, and "Arekom-4" (TU 2481-007-11084661-2003) - foaming agent, which is an aqueous solution of anionic surfactants and auxiliary additives; as a solvent, we used water that meets the requirements of GOST 23732-79 (State Committee of the USSR for Construction, Ministry of Energy and Electrification of the USSR, 1993).

We carried out the activation of water and aqueous solutions using the unit for the anti-scale treatment of water systems UPOVS2-5.0 by "Maxmir" (Yuvshin et al., 2004). We conducted experimental research in accordance with the operation modes of the apparatus. In total, we used nine modes, the cipher of which is composed of alphanumeric characters. The letter designation $\mathrm{E}+\mathrm{M}$ means that the natural water or its solution has been subjected to joint successive activation by an electric current (electrochemical activation) and an electromagnetic field in the working gaps of the apparatus. The digital designation corresponds to the selected mode of operation of the device, which characterizes the current strength (switch position) in the cell circuit and the winding of the magnetizing coils. The modes and their parameters are presented in Table 1.

We used a stalagmometric method to study the indicator of the critical micelle concentration of Arekom-4. The surface tension values of the solutions are shown in Table 2. The critical concentration of Arekom-4 foaming agent was calculated for each type of water according to the curves of the surface tension versus the concentration of the foaming agent. The values of the CMC are given in Table 2.

Based on the tabulated values of the surface tension of the solutions, we constructed the graphical dependencies shown in Fig. 1.

We can see that the curves of the dependence of the surface tension on the concentration of the foaming agent for some types of activated water (1-3, 3-3 and 6-3) differ

Table 1 Activation modes of water and aqueous solutions

\begin{tabular}{lcc}
\hline $\begin{array}{l}\text { Water activation } \\
\text { mode }\end{array}$ & $\begin{array}{c}\text { Current density } j_{\max }, \\
\mathrm{A} / \mathrm{m}^{2}\end{array}$ & $\begin{array}{c}\text { Electromagnetic field } \\
\text { strength } H_{\max }, \mathrm{kA} / \mathrm{m}\end{array}$ \\
\hline $\mathrm{E}+\mathrm{M}(1-1)$ & 5.65 & 24 \\
$\mathrm{E}+\mathrm{M}(1-3)$ & 5.65 & 75 \\
$\mathrm{E}+\mathrm{M}(1-6)$ & 5.65 & 135 \\
$\mathrm{E}+\mathrm{M}(3-1)$ & 22.58 & 24 \\
$\mathrm{E}+\mathrm{M}(3-3)$ & 22.58 & 75 \\
$\mathrm{E}+\mathrm{M}(3-6)$ & 22.58 & 135 \\
$\mathrm{E}+\mathrm{M}(6-1)$ & 43.55 & 24 \\
$\mathrm{E}+\mathrm{M}(6-3)$ & 43.55 & 75 \\
$\mathrm{E}+\mathrm{M}(6-6)$ & 43.55 & 135 \\
\hline
\end{tabular}


Table 2 Dependence of the surface tension of activated water on the concentration of Arekom-4 foaming agent

\begin{tabular}{|c|c|c|c|c|c|c|c|}
\hline Water & \multicolumn{6}{|c|}{ Surface tension, $\mathrm{mJ} / \mathrm{m}^{2}$} & $\mathrm{CMC}$, \\
\hline 0 & 72.75 & 34.68 & 29.50 & 29.05 & 27.79 & 27.88 & 0.26 \\
\hline $\begin{array}{l}E+M \\
(1-1)\end{array}$ & 72.75 & 34.96 & 29.00 & 28.32 & 27.53 & 27.28 & 0.25 \\
\hline $\begin{array}{l}E+M \\
(1-3)\end{array}$ & 72.75 & 33.02 & 28.33 & 27.96 & 27.45 & 26.63 & 0.25 \\
\hline $\begin{array}{l}E+M \\
(1-6)\end{array}$ & 72.75 & 35.79 & 30.00 & 28.87 & 27.19 & 26.09 & 0.24 \\
\hline $\begin{array}{l}E+M \\
(3-1)\end{array}$ & 72.75 & 34.28 & 30.03 & 29.19 & 27.45 & 26.36 & 0.24 \\
\hline $\begin{array}{l}E+M \\
(3-3)\end{array}$ & 72.75 & 36.23 & 30.96 & 29.89 & 27.79 & 26.79 & 0.24 \\
\hline $\begin{array}{l}E+M \\
(3-6)\end{array}$ & 72.75 & 34.62 & 30.39 & 29.76 & 28.32 & 26.95 & 0.26 \\
\hline $\begin{array}{l}E+M \\
(6-1)\end{array}$ & 72.75 & 34.55 & 30.10 & 29.05 & 28.23 & 26.79 & 0.24 \\
\hline $\begin{array}{l}E+M \\
(6-3)\end{array}$ & 72.75 & 36.53 & 29.13 & 27.28 & 26.95 & 26.87 & 0.27 \\
\hline $\begin{array}{l}E+M \\
(6-6)\end{array}$ & 72.75 & 35.37 & 30.54 & 29.53 & 27.28 & 26.79 & 0.25 \\
\hline $\mathrm{W}, \%$ & 0.0 & 0.2 & 0.4 & 0.6 & 1.0 & 2.0 & \\
\hline
\end{tabular}

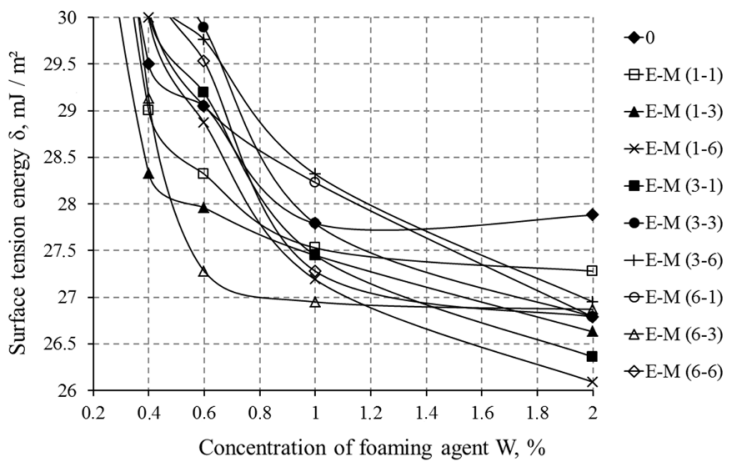

Fig. 1 Dependence of surface tension on the concentration of foaming agent

slightly from the other curves. However, there is no sharp difference between them. From the results of studies it follows that the critical concentration of foaming agent Arekom-4 is in the range $0.2 \ldots 0.3 \%$.

Various properties of the foam influence on the structure formation and hardening of the foam mass, they affect the subsequent performance of buildings constructed from foam concrete.

To assess the quality of foaming of the solutions and the prepared foams we have investigated the multiplicity and stability of foam. We determined the foam multiplicity of Arekom-4 and Esapon 1812 foaming agents in accordance with TU 2481-007-11084661-2003. As a solvent for foaming agents, we used non-activated water and water activated according to the regimens given in Table 1. Test results for the determination of the foam multiplicity for Arekom-4 and Esapon 1812 foaming agents with the use of activated water are shown in Fig. 2.

It follows from Fig. 2 that with increasing current in the conductor of magnetizing coils and in the working gap of the electrodes, the multiplicity of the foam increases.

We determined the stability of the foam in accordance with TU 2481-007-11084661-2003. The results of tests for determining foam stability of foaming agent Arekom-4 and Esapon 1812 using activated water are shown in Fig. 3.

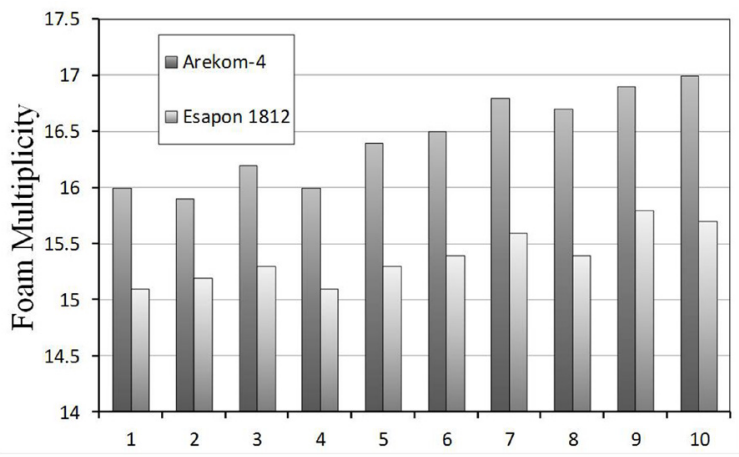

Fig. 2 Change of the foam multiplicity for Arekom-4 and Esapon 1812 on the mode of water activation: 1) non-activated water; 2) water activated according to the "E + M (1-1)"; 3) water activated according to the "E + M (1-3)"; 4) water activated according to the "E + M (1-6)"; 5) water activated according to the "E + M (3-1)"; 6) water activated according to the "E + M (3-3)"; 7) water activated according to the "E + M (3-6)"; 8) water activated according to the "E + M (6-1)"; 9) water activated according to the "E + M (6-3)";

10) water activated according to the "E + M (6-6)"

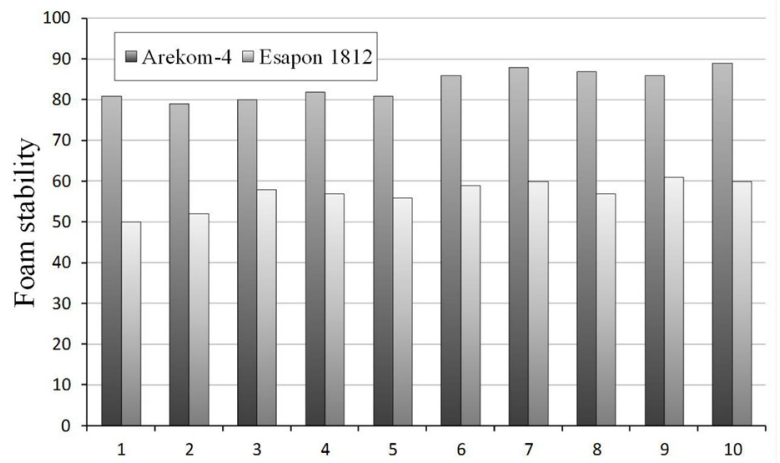

Fig. 3 Change of the foam stability for Arekom-4 and Esapon 1812 on the mode of water activation: 1) non-activated water; 2) water activated according to the "E + M (1-1)"; 3) water activated according to the "E + M (1-3)"; 4) water activated according to the "E + M (1-6)"; 5) water activated according to the "E + M (3-1)"; 6) water activated according to the "E + M (3-3)"; 7) water activated according to the "E + M (3-6)"; 8) water activated according to the "E + M (6-1)"; 9) water activated according to the "E + M (6-3)"; 10) water activated according to the "E + M (6-6)" 
It follows from Fig. 3 that with increasing current in the conductor of magnetizing coils and in the working gap of the electrodes, the stability of the foam increases with the use of both types of foaming agents.

Obtaining an effective insulating material with low density (less than $500 \mathrm{~kg} / \mathrm{m}^{3}$ ) and low thermal conductivity remains one of the main tasks in the production of foam concrete. For its implementation, it is necessary to pay special attention to the technology of manufacturing this material, in particular, to the choice of the foaming agent type, the selection of the water-hard ratio, and the quality of the cement. Modification of the mixing water will have a definite effect on the material properties of cellular structure.

We examined the foam concrete on 2 types of foaming agent: Arekom-4 and Esapon 1812. We present the results of the dependence of the foam concrete strength on the water activation mode in Figs. 4 and 5.

We can see from Figs. 4 and 5 that the use of activated mixing water promotes an increase in the strength characteristics of composites. The water treated by the combined action of electric current and magnetic field makes it possible to increase the compressive strength of foam concrete on the Arekom-4 up to $90 \%$, and on the Esapon 1812 - up to $18 \%$.

Shrinkage is an important property of foam concrete. Shrinkage of foam concrete during drying should not exceed $3 \mathrm{~mm} / \mathrm{m}$ (for non-autoclave technology materials according to the requirements of GOST 25485-2019 (NIIZHB named after A. A. Gvozdev, 2019)). Otherwise, the shrinkage strain will cause cracking. This is especially observed in the case of manufacturing large-size products, which include wall

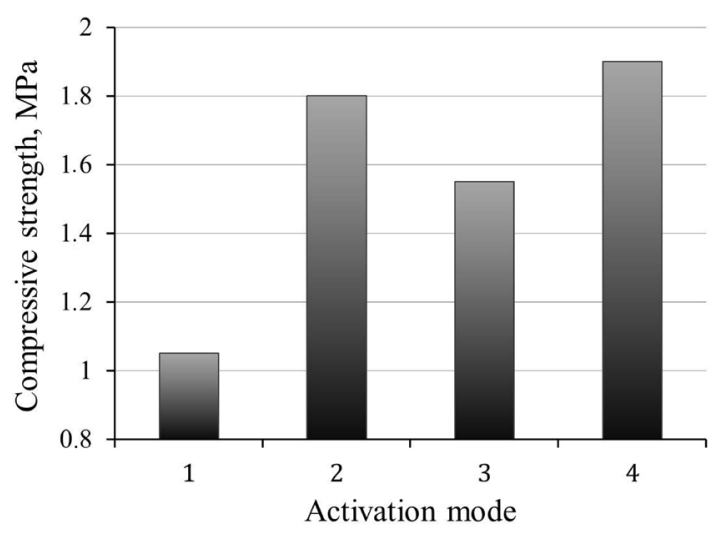

Fig. 4 Dependence of the change in compressive strength of foam concrete with the foaming agent Arekom-4 on the type of activated mixing water: 1) water not activated; 2) the same, processed by a magnetic field; 3) the same, treated by electric current; 4) the same, treated by the combined action of an electric current and a magnetic field

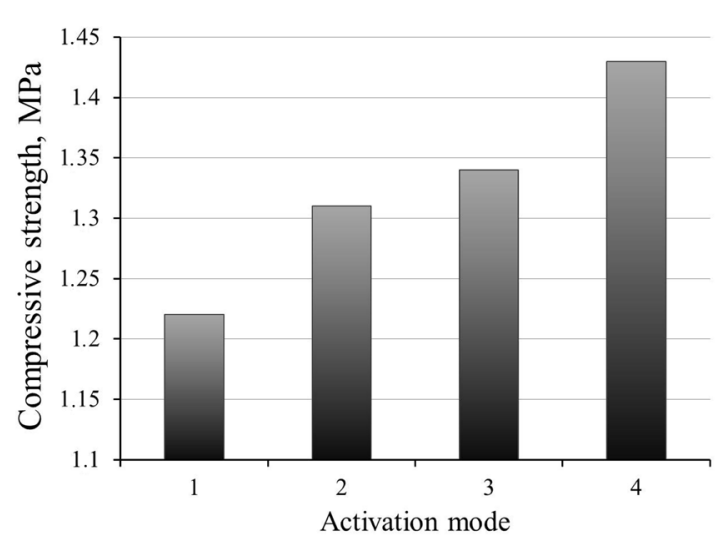

Fig. 5 Dependence of the change in compressive strength of foam concrete with the foaming agent Esapon 1812 on the type of activated mixing water: 1) water not activated; 2) the same, processed by a magnetic field; 3) the same, treated by electric current; 4) the same, treated by the combined action of an electric current and a magnetic field

structure and slab coverings. According to practical experience of foam concrete application, the width of crack opening in similar products can reach $3 . . .5 \mathrm{~mm}$.

When performing research, the shrinkage was determined on samples in the form of prisms of size $4 \times 4 \times 16 \mathrm{~cm}$. Deformations were measured by dial indicators. Study results of the foam concrete shrinkage (samples were composed with the use of two types of foaming agents and activated mixing water) are shown in Figs. 6 and 7.

From the data given, we can see that the greatest growth of shrinkage deformations occurs in the first 5-7 days, and then stabilization of shrinkage is observed. It also follows from the results of investigations that the treatment of activated mixing water by electromagnetic field and electric current helps to reduce shrinkage deformations. Here, apparently, a significant role is played by the dispersed phase formed as a result of the mixing water activation. From the

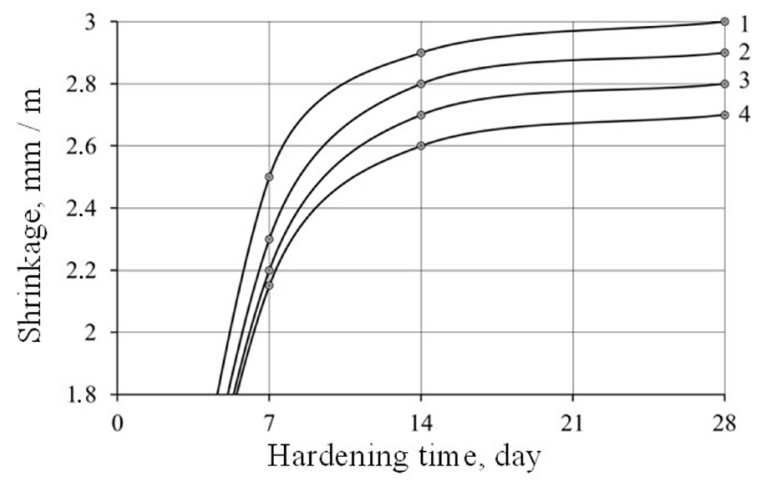

Fig. 6 Dependence of foam concrete shrinkage with foaming agents "Esapon 1812" on the activation mode of mixing water: 1) water not activated; 2 ) water activated by the $\mathrm{E}+\mathrm{M}$ mode $(1-1) ; 3)$ the same, $\mathrm{E}+\mathrm{M}(3-3) ; 4)$ the same, $\mathrm{E}+\mathrm{M}(6-6)$ 


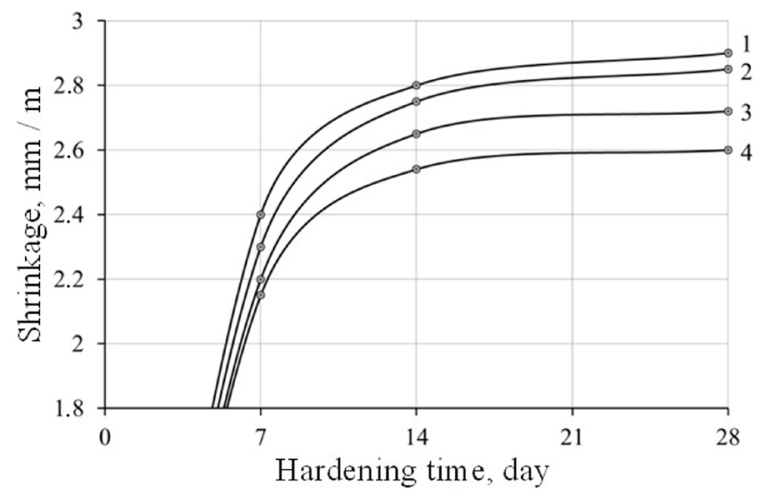

Fig. 7 Dependence of foam concrete shrinkage with foaming agents "Arekom-4" on the activation mode of mixing water: 1) water not activated; 2) water activated by the $\mathrm{E}+\mathrm{M}$ mode (1-1); 3) the same, $\mathrm{E}+\mathrm{M}(3-3) ; 4)$ the same, $\mathrm{E}+\mathrm{M}(6-6)$

considered activation variants, the $\mathrm{E}+\mathrm{M}$ mode (6-6) is the best of them. In this case, shrinkage reduction is more than $10 \%$. The tests also showed that less shrinkage occurs in the materials on the Arekom-4 foaming agent.

It is well known that foam concrete quickly absorbs water into its pores during operation in conditions of high humidity or while standing in water. The change in the moisture content of concrete affects not only its insulating properties. This phenomenon is also associated with the development of moisture shrinkage. In the presence of moisture, the material swells, and when dried, it shrinks. Emerging stresses (due to changes in humidity) loosen the structure of the material and reduce its strength. Humidity deformations, in the first place, depend on the ratio of gel-like and crystalline phases in the cement stone. The resistance of the material increases in such conditions with increasing crystalline phase. In this case, it is important to increase the strength of the structural mesh from the hardened cement stone in the porous system. Previous studies (Deuse et al., 2009; Kalashnikov, 2011) showed that mixing cement with activated water, contributes to a significant increase in strength of cement stone. It was found that with the same degree of hydration and porosity, the strength of the cement stone depends on the nature of the hydrates crystallization. The high strength of cement stone was noted in the compositions with the optimal combination of weakly crystallized hydrates with dense sections of the crystallized structure. Weakly crystallized hydrosilicates are apparently a binder cementing unreacted clinker grains, as well as crystals of calcium hydroxide and ettringite hydroxide. The density of the material significantly affects the water resistance of the cement compositions, in addition to the above factors. One of the main factors affecting the density, regardless of the initial water-cement ratio, is the form of water-solid interface. Water, as known, is one of the main elements that form the structure of cement stone; water is involved in the formation of hydrate compounds and the formation of pores.

Studies of the water resistance of foam concrete were carried out on samples measuring $4 \times 4 \times 16 \mathrm{~cm}$. The test results of samples after 3 days of incubation in the environment shown in Fig. 8.

Studies show an increase in the water resistance of foam concrete prepared on activated mixing water, compared with the control compositions on average by $10 \%$.

The study of the corrosion resistance of the reinforcement was carried out using activated mixing water in the presence of plasticizing additives and fillers of different nature.

Thus, the electrochemical potential of corrosion-free steel 85 in water " 0 " is in the region of negative values and is insignificant in its magnitude $(\varphi=-0.2 \mathrm{~V})$. When the potential is shifted to a positive area, there is a tendency to a noticeable deceleration of the anode process. The Tafel dependence of the anode process overvoltage on the current density with an angular coefficient $\beta=\operatorname{tg} \alpha=0.155$ is recorded on the site $\varphi=-0.2 \ldots-0.06$ of the anode polarization curve (Fig. 9, curve 1).

The addition of white soot to the water, with appropriate electromagnetic treatment, does not violate the laws in the anode behavior of steel 85. With the increase of the anode polarization potential, in the mode of electromagnetic processing of $\mathrm{E}+\mathrm{M}$ (6-6), there is an increase in the dissolution currents (Fig. 9).

The addition of talc to water does not significantly change the electrochemical characteristics of steel 85 , but at the same time there is a small shift in the potential of

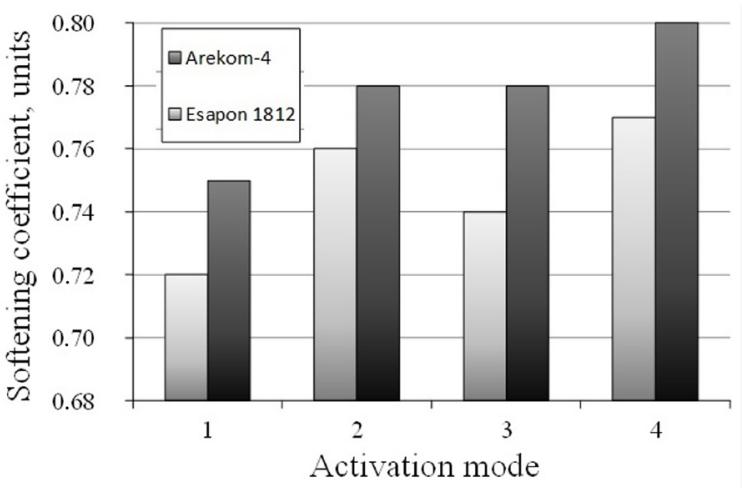

Fig. 8 Dependence of the softening coefficient of foam concrete on the mixing water activation mode: 1 ) water not activated; 2$)$ water activated by the $\mathrm{E}+\mathrm{M}$ mode $(1-1) ; 3)$ the same, $\mathrm{E}+\mathrm{M}(3-3)$; 4) the same, E + M (6-6) 


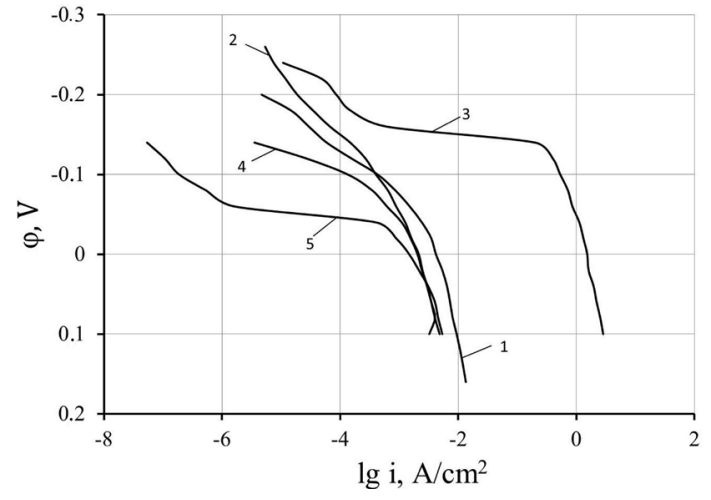

Fig. 9 Anodic polarization curves for water in the presence of additive "white soot": 1) water not activated; 2) water is not activated with the addition; 3 ) water activated with the addition by the $\mathrm{E}+\mathrm{M}$ mode (1-1); 4) the same, E+ M (3-3); 5) the same, E + M (6-6)

the negative region and an increase in the dissolution currents compared to water without additives. The pre-logarithmic coefficient in the Taffle-talc equation is 0.875 . Consequently, the additive slows down the anode dissolution process starting from the value of the free corrosion potential equal to $-0.19 \mathrm{~V}$ to $+0.25 \mathrm{~V}$ (Fig. 10, curve 1).

Notes the plot Tafel direct with talc prelogarithmic coefficient $\beta=0.155$. Anodic polarization curves obey the General rule: increasing the ratio of electric current to magnetic field activates anodic dissolution of reinforcing steel in solution.

The results of the experiment of the anode behavior of steel 85 showed that the studied additives, depending on their chemical composition, have a different aggressive effect on the steel. Probably, the electrochemical characteristics obtained in the process of anodic polarization of steel in water with additives also depend on electromagnetic treatment, which in turn makes changes in the electrical properties of water, changing its oxidation-reduction potential.

\section{References}

Bazhenov, Y. M., Fedosov, S. V., Erofeev, V. T., Matviyevsky, A. A., Mitina, E. A., Emelyanov, D. V., Yudin, P. V. (2011) "Цементные композиты на основе магнитно- и электрохимически активированной воды затворения" (Cement composites based on magnetically and electrochemically activated mixing waters), Mordovia State University Press, Saransk, Russia. (in Russian)

Deuse, T., Hornung, D., Mollmann, M. (2009) "Von der Mikrodur Zur Nanodur-Technologie - Normzement zur praxisgerechten Herstellung von UHPC" (From Mikrodur to Nanodur technology - Standard cement for practice-oriented manufacture of UHPC), Betonwerk und Fertigteil-Technik, 75(5), pp. 4-15. (in German)

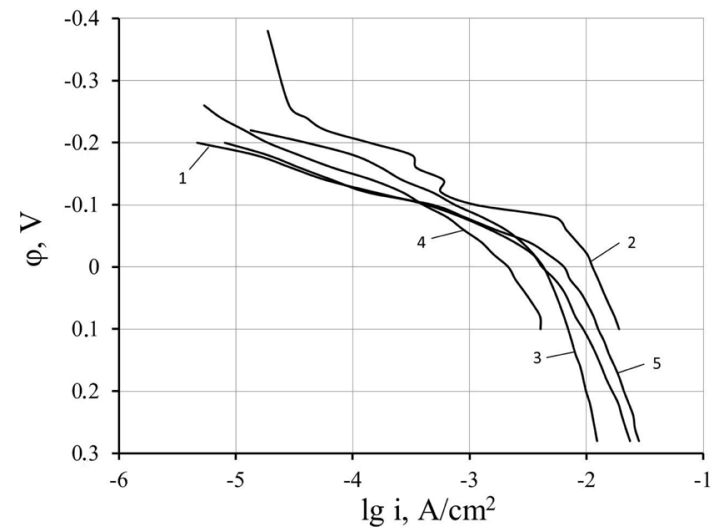

Fig. 10 Anodic polarization curves for water in the presence of additive "talc": 1) water not activated; 2) water is not activated with the addition;

3) water activated with the addition by the $\mathrm{E}+\mathrm{M}$ mode (1-1); 4) the same, E+M (3-3); 5) the same, E+ M (6-6)

\section{Conclusion}

The technology of electrochemical and electromagnetic mixing water activation makes it possible to get a foam with higher stability and multiplicity. The presented technology contributes to obtaining a foam concrete matrix with improved physical-mechanical and operational parameters. Activation of the mixing water allows to increase the compression strength of foam concrete up to $90 \%$, increase water resistance by $10 \%$ and reduce shrinkage. Studies have established the possibility of using metal reinforcement in foam concrete on activated mixing water.

\section{Acknowledgement}

The project presented in this article is supported by RFFI and the government of the Republic of Mordovia No. 18-48-130014 "Foam concrete on the basis of electrochemical and electromagnetic-activated mixing water".

Emelyanov, D. V., Erofeev, V. T., Balathanova, E. M., Markov, S. V., Golubka, A. I. (2014a) "Исследование цементных композитов с добавкой тонкодисперсных частиц речного известняка" (Research of cement composites with the addition of fine particles of limestone), Natural and Technical Sciences, 9-10(77), pp. 423-425. (in Russian)

Emelyanov, D. V., Erofeev, V. T., Balathanova, E. M., Markov, S. V., Senyutin, A. V. (2014b) "Исследование цементных композитов с добавкой горного известняка" (Study of cement composites with the addition of rock limestone), Natural and Technical Sciences, 9-10(77), pp. 426-428. (in Russian) 
Erofeev, V. T., Mitina, E. A., Matvievsky, A. A., Osipov, A. K., Emelyanov, D. V., Yudin, P. V. (2007) "Композиционные строительные материалы на активированной воде затворения" (Composite building materials on activated mixing water), Building Materials, 11, pp. 56-58. (in Russian)

Erofeev, V. T., Mitina, E. A., Matvievsky, A. A., Emelyanov, D. V., Yudin, P. V. (2008) "Долговечность цементных композитов на активированной воде" (Durability of cement composites activated water), Industrial and Civil Construction, 7, pp. 51-53. (in Russian)

Erofeev, V. T., Bazhenov, Y. M., Balathanova, E. M., Mitina, E. A., Emelyanov, D. V., Rodin, A. I., Karpushin, S. N. (2014) "Получение и физико-механические свойства цементных композитов с применением наполнителей и воды затворения месторождений чеченской республики" (Production and physico-mechanical properties of cement composites with fillers and gauging water from the Chechen Republic), Vestnik MGSU, 12, pp. 141-151. (in Russian)

Fedosov, S. V., Akulova, M. V., Slizneva, T. E., Kasatkina, V. I., Padokhin, V. A. (2011) "Анализ фазовых превращений в мелкозернистом бетоне на механомагнитоактивированной воде затворения в присутствии NA-КМЦ" (Analysis of phase transformations in fine-grained concrete on machinemanufacturer the mixing water in the presence of $\mathrm{Na}-\mathrm{Carboxymethylcellulose),}$ Vestnik MGSU, 1(1), pp. 238-243. (in Russian)

Fokin, G. A., Loshkanova, Y. А. (2008) "Повышение физикомеханических свойств цементных систем акустической активацией воды затворения" (Increase of physical and mechanical properties of cement systems using acoustic activation of mixing water), Izvestiya Vysshikh Uchebnykh Zavedenii. Stroitelstvo, 4, pp. 16-20. (in Russian)

Kalashnikov, V. I. (2011) "Терминология науки о бетонах нового поколения / В. И. Калашников" (The terminology of the science of concretes of a new generation), Building Materials, 10, pp. 103-106. (in Russian)

Kalashnikov, V. I. Erofeev, V. T., Morozova, M. N., Troyanov, I. Y., Volodin, V. M., Suzdaltsev, O. V. (2014) "Наногидросиликатные технологии в производстве бетона" (Nanohydrosilicate technologies in the concrete production), Building Materials, 5, pp. 88-91. (in Russian)

Karaseva, I. A. (2008) "Повышение эффективности цементных дисперсных систем водой в метастабильном состоянии : автореферат дис. кандидата технических наук" (Improving the efficiency of cement dispersing systems water in metastable state. An abstract of the thesis of candidate of technical Sciences), PGUAS, Penza, Russia.
Karpenko, N., Erofeev, V., Emelianov, D., Fomichev, V., Bulgakov, A. (2018) "Technology, structure formation and properties of foam concrete on activated water of mixing", In: Creative Construction Conference 2018, CCC 2018, Ljubljana, Slovenia, pp. 213-219. https://doi.org/10.3311/CCC2018-028

Kruglyakov, P. M., Exorova, D. R. (1990) "Пена и пенные пленки" (Foam and foam films), Moscow Chemistry, Moscow, Russia.

LLCCemiskon(2016)"ГОСТ31108-2016.Цементыобщестроительные. Технические условия" (GOST 31108-2016. Common cements. Specifications), Publishing House of Standards, Moscow, Russia. (in Russian)

NIIZHB named after A. A. Gvozdev (2019) "ГОСТ 25485-2019. Бетоны ячеистые. Общие технические условия" (GOST 25485-2019. Cellular concretes. General specifications), Standartinform, Moscow, Russia. (in Russian)

Portik, А. А. (2003) "Все о пенобетоне" (All about foam concrete), Stroi Beton Publishing House, St. Petersburg, Russia. (in Russian)

Povkh, I. L., Sovpel, V. B., Bychin, N. А. (1971) "Магнитная и электролитическая обработка воды при производстве бетона" (Magnetic and electrolytic treatment of water in the concrete production), In: Problems of theory and practice of magnetic water treatment and water systems, Moscow, Russia, pp. 227-228. (in Russian)

State Committee of the USSR for Construction, Ministry of Energy and Electrification of the USSR (1993) "ГОСТ 23732-79. Вода для бетонов и растворов. Технические условия" (GOST 2373279. Water for concretes and mortars. Specifications), Publishing House of Standards, Moscow, Russia. (in Russian)

Ulazowski, V. L., Ananina, A. S. (1975) "К вопросу о механизме магнитной обработки воды и стабильности эффекта затворения ею вяжущих и бетона" (To the question about the mechanism of magnetic treatment of water and the stability of the effect of mixing it binders and concrete), In: Problems of theory and practice of magnetic water treatment and water systems, Moscow, Russia, pp. 204-207. (in Russian)

Yuvshin, A. S., Matvievsky, A. A., Ovchinnikov, V. G. (2004) "Устройство для магнитной обработки водных систем и установка для обработки водных систем" (Device for magnetic treatment of water systems and plant for processing water systems), Moscow, No. 2223235. 